Revista Iberoamericana, Vol. LXVIII, Núm. 201, Octubre-Diciembre 2001, 1041-1065

\title{
LAS PALABRAS PERDIDAS (JESÚS DÍAZ) O DEL LUGAR DE LA LITERATURA
}

POR

GISELA KozAK

Universidad Central de Venezuela

\section{¿PARA QUÉ NARRAR?}

Las palabras perdidas (1992), de Jesús Díaz (Cuba, 1941), está constituida por diversos géneros literarios y no literarios — cuentos, poemas, entrevistas, prólogos — que dan cuenta de toda una manera de ver la escritura, la sociedad y la vida que, desde una perspectiva hondamente vital aunque desencantada, nos lleva a recorrer algunos de los grandes tópicos políticos, culturales y literarios del siglo veinte latinoamericano: el papel de la literatura en la vida individual y colectiva, sus avatares frente al quehacer político, en qué sentido se constituye en una forma de vida y de ver el mundo - prácticamente en una religión-, y su significación en términos de una suerte de modernidad compensatoria (Beverly 28; Avelar 42), que de algún modo satisfacía una apetencia de transformación cultural e imaginaria que las condiciones socioeconómicas y políticas del continente no brindaban.

El interés de Las palabras perdidas en este sentido reside en que estas temáticas se convierten en la carne y en la sangre de la narración, a través de la reflexión permanente sobre el proceso de la escritura literaria desde un punto de vista que privilegia el aquí y ahora, es decir, desde la conciencia de la existencia del campo literario como campo de poder, y desde la conciencia de que la literatura hoy día no puede asentarse simplemente en los viejos fueros de la originalidad y el sacerdocio estético. Así, por una parte se contemplan críticamente las grandezas y mezquindades de una manera de ver el mundo que marcó el ámbito latinoamericano letrado, o, más específicamente y en palabras de Bourdieu, ${ }^{1}$ nuestro campo literario, y se explicitan las condiciones mismas de funcionamiento de ese campo, desde el punto de vista de un ejercicio soterrado del poder y de una manera de divinizar un oficio socialmente dudoso: el Flaco, Rojo, Una y el Gordo

\footnotetext{
${ }^{1}$ En Las reglas del arte. Génesis y estructura del campo literario, Pierre Bourdieu destaca las características del campo literario visto como un campo de fuerzas cuyas reglas de funcionamiento se formulan en su interior mismo. La autonomía radical del campo literario es una herencia del siglo XIX, y presupone el mito de la libertad absoluta del artista en tanto creador libre de toda constricción social o política, las instancias institucionales de consagración -académicas, editoriales, público ilustrado-, y la oposición encarnizada entre distintas estéticas, y entre éstas y él como condición sine qua non para obtener el control del capital simbólico.
} 
— personajes protagónicos radicados en La Habana a finales de los sesenta — tratan, cada uno a su manera, de hacerse con el poder simbólico — dado por el dominio del canon y la práctica de la escritura-, ser escuchados, cambiar la literatura y derribar todas las convenciones posibles. Por otra, la novela reflexiona sobre la obsesión por la novedad, propia de las grandes estéticas latinoamericanas, norteamericanas y europeas de buena parte del siglo $\mathrm{xx}$, y la reconoce con respeto, al mismo tiempo que la cuestiona en el proceso narrativo mismo. El texto cita, plagia, saquea géneros asumiendo abiertamente que, a finales del siglo xx, la orientación de la producción literaria no es precisamente lograr la originalidad más radical, sino más bien la apertura y la mixtura estéticas (Yúdice 122-23). Además, y más allá de los problemas de la escritura propiamente dicha, Las palabras perdidas es una reflexión sobre el papel de la literatura en un mundo que, en apariencia, no pareciera requerirla especialmente. ¿Sirve de algo enfrentar el desprecio y la locura sólo para rescatar las palabras de un grupo de muchachos problemáticos? ¿Sirve de algo enfrentar al estado cubano y volver a un pasado terrible sólo por rescatar unos textos de una revista literaria que no llegó a publicarse y por salvar de la nada las experiencias de unos escritores desconocidos? La obsesión del narrador es contestarse estas preguntas y la novela se constituye como la respuesta a las mismas. Como dice Idelber Avelar:

1)¿Cuáles son las condiciones de transmisibilidad de la experiencia personal en una sociedad dominada por la automatización y la mercancía? ¿A quién le puede interesar narrar la experiencia en un momento histórico en el cual el relato ha sido reemplazado por la información? 2)¿Qué papel puede tener la literatura después de rotos sus lazos con la memoria colectiva? Para el sujeto estético que nace con Baudelaire, ¿qué queda de narrable en la experiencia? (38)

Una posible respuesta a estas preguntas es que Las palabras perdidas intenta -al igual que mucha de la literatura hispanoamericana actual— ofrecer una "estrategia restitutiva-simbólica” (Avelar 40) que trae al presente un pasado que se nos escapa, pues vivimos un tiempo “exento de la discursividad histórica” (Salaber 16), es decir, un tiempo en el que los acontecimientos y la propia experiencia escapan de la sintaxis y la coherencia del relato de la historia y del relato literario, y se convierten en un simple "pasar sin trascender" (Salaber 17). Por eso, el narrador de Las palabras perdidas desea rescatar las palabras y las vivencias de sí mismo y de sus compañeros de lucha literaria del olvido; no quiere que su experiencia y sus escrituras fenezcan en un anonimato feroz, después de que todos han muerto y han arriesgado sus vidas por la palabra. El Rojo, Una, el Gordo y el Flaco, protagonistas de esta aventura literaria en La Habana de la Revolución, a finales de los sesenta, son un grupo de escritores jóvenes que responde al moderno y vanguardista impulso de renovar radicalmente la literatura cubana, deslumbrada por sus figuras tutelares — Nicolás Guillén, Eliseo Diego, José Lezama Lima, Alejo Carpentier y Virgilio Piñera- y en permanente tensión con los intereses de la revolución política más famosa de América Latina. Los tres jóvenes y la muchacha coinciden en un proyecto de revista literaria que desea seguir la huella trazada por las publicaciones periódicas del continente, y convertirse en un centro de lucha estética, que no es más que una lucha por los modos 
de representación literaria y su vinculación con el mundo social y cultural. Los cuatro parecen pichones de escritores del “boom” vistos con la mirada juguetona y desencantada de la narrativa de las últimas décadas.

Y por tener esta perspectiva, en Las palabras perdidas la pasión por la literatura implica la comprensión de que el mundo ha cambiado, que hoy no podemos hablar de guerra sino de convivencia entre estéticas, y que éstas implican desde el punto de vista cultural maneras de modelar y entender el mundo, y, por supuesto, de narrar las experiencias. En esta novela la cotidianeidad de una ciudad pobre, bella y moribunda es vista desde las palabras de los grandes poetas cubanos — Lezama, Diego, Guillén — sin encubrir un ápice de su horror y tampoco de su maravilla, y cada personaje nos es presentado como una lengua, una escritura, una percepción literaria de sí mismo y de lo que le rodea. La representación es, pues, la posibilidad de ofrecer un modelo de mundo que al ser constituido en y por el lenguaje, no es una simple traducción de determinados estados de cosas sino que conforma lo real y nos introduce en complejas configuraciones culturales (Prada Oropeza 30). Por tal razón, la estética vanguardista del Rojo nos pone en contacto con una cosmovisión universalista que define desde el papel del lenguaje, pasando por la discusión sobre la cultura nacional en pugna con las influencias internacionales, hasta la visión sobre el rol profético y principesco del escritor. Las propuestas del Flaco atacan a una corriente clave dentro de la literatura y el arte continentales: cómo apropiarse de los registros de lo oral y lo popular y entender la posición de lo subalterno desde los privilegios de la cultura letrada. El Gordo pugna por una cosmovisión urbana que haga oír el lenguaje de la calle y se mantenga equidistante del universalismo olímpico del Rojo y del realismo del Flaco. Una busca ampliar el canon literario introduciendo a las mujeres, impone agresivamente el derecho a apropiarse de la herencia literaria femenina y masculina y reinterpretarla desde la opresión de la mujer, y rescata el papel de la subjetividad — entendida en este caso como las marcas de génerofrente a los arrestos de pequeños demiurgos de sus compañeros de lucha literaria.

Desde estos personajes y concepciones de lo literario tan distintas, Las palabras perdidas nos pone en contacto con los avatares y contradicciones de las culturas latinoamericanas, la literatura y la revolución, las diferencias entre las percepciones y actuaciones de los sujetos femeninos y masculinos, el papel de los intelectuales, el totalitarismo, las contradicciones entre cultura oral y escrita, la marginalidad, el amor y el sexo, el arte como emancipación y esclavitud. La representación —la lucha por los modos de representar - es en esta novela un delicado trabajo en el que se utilizan códigos literarios muy diversos para "construir y producir esos efectos de presencia y significación” (Richard, La insubordinación... 103), que en este caso permiten la emergencia de las “estructuras del sentir” (Williams 154-55), es decir, la plasmación literaria de las vivencias concretas de un grupo de jóvenes de distinta procedencia, género y visiones de mundo, unidos en sus aventuras en el campo literario, frente a una Revolución que hipertrofió la esfera del Estado hasta convertirla en la única instancia de sentido y pertenencia individuales y colectivos. En este sentido, Las palabras perdidas se suma a los numerosos relatos sobre la juventud, sobre los marginales y sobre la rebelión contra el poder como instancia inscrita en la vida cotidiana (Rama 187) que han distinguido la narrativa que a mediados de los ochenta recibió el nombre de "postboom”.

LA HERENCIA CERVANTINA: EL NOVELISTA COMO CRÍTICO LITERARIO 
Creo que uno de los caminos más fecundos para abordar Las palabras perdidas es entenderla como una puesta en escena de un proceso de creación, difusión y recepción de textos poéticos y narrativos, que constituye el universo ficticio desde una actitud de contextualización, análisis y reflexión propia de la crítica literaria. Por un lado, tenemos los procesos creativos personales de los personajes y su filiación a determinada corriente literaria; por otro, se nos indica la primera recepción de sus trabajos —los escritores del grupo- - y el proyecto de divulgarlos a través de la revista El Güije Ilustrado; por último, se nos orienta en relación con las tendencias globales de la literatura cubana y su tensión con el entorno político, y se expone el grave problema del Flaco, el único sobreviviente, para años después darle forma a toda esta historia colectiva. El Flaco debe fungir de crítico y de novelista, valorar de manera adecuada y justa, y pensar en las consecuencias de publicar un texto que implica una doble denuncia frente al estado cubano: la de los escritores silenciados y la suya propia.

La novela está estructurada en dos planos diferenciados espacial y temporalmente. Por un lado, nos encontramos con los capítulos que refieren la vida de los jóvenes protagonistas y el nacimiento y muerte de la revista El Güije Ilustrado, los cuales se organizan y se relacionan a través de la palabra del narrador, que narra predominantemente en estilo indirecto, pero desde la perspectiva de los distintos personajes principales: Rojo, el Flaco, el Gordo y Una. Por otra, tenemos una serie de capítulos titulados "Torre Oskántino”, en los que casi una década después el Flaco, sentado en el restaurante de la torre con un mediocre escritor —el Rubito- convertido en un diplomático importante en la otrora Unión Soviética, se halla en el extremo opuesto de cuando era un joven narrador lleno de planes y con la cabeza puesta en hacer "gran literatura”. Ahora es un constructor, con esposa e hija, que consiguió por fin una casa en donde vivir, y trata de recuperar, por medio del poder burocrático del Rubito, a su hijo Osip, un niño ruso producto de una aventura juvenil con una rusa llamada Irina (93). El juego entre la biografía temprana del Flaco, sus obras de juventud, su vida actual, es permanente. Como el personaje Candelaria Cárdenas, de su cuento "Flores para tu altar”, que se suicida prendiéndose fuego (107), el Flaco quema la tienda de campaña en la que vivía cuando fue enviado a reeducarse al campo (346) a raíz de la prohibición de publicación de El Güije Ilustrado. La obsesión por el fuego purificador es también el recuerdo de los ritos de Nuestra Amada Kaär, la civilización inventada por el Rojo, los cuales intentan expiar las culpas de un pueblo que olvidó las palabras (158). Pero lo más terrible no son ni siquiera los ritos de expiación, sino la prohibición misma del rito, la prohibición del acto mismo de recordar. La locura lo termina apartando de la literatura y de su vida pasada, y el Flaco paga así su silencio culpable ante los burócratas cubanos cuando rechazan los textos de El Güije Ilustrado. Pero una inquietud lo lacera permanentemente, al pensar en sus amigos Rojo, el Gordo y Una, ya muertos:

El Flaco sintió que se erizaba; justamente de la obsesión de aquellas muertes había surgido la idea de la novela, como si fuera destinatario de un destino común que hasta ahora no había tenido el valor o el talento para cumplir y que lo condenaba maniáticamente a volver sobre los viejos textos, los mismos que necesitaba rescatar del olvido. ¿ Tendría derecho a utilizarlos en la novela, salvando así la fácil tentación de una antología? ¿Sería 
capaz de presentarlos de un modo orgánico, con el oficio suficiente para hacer de su libro algo más que un cajón de sastre? ¿Cómo lograrlo, sino aparecieran en principio recreándose a sí mismo y a sus hermanos de modo que las respectivas opciones literarias no como resultados sino como procesos? ¿Valdría la pena empeñarse en aquel trabajo de Sísifo por un libro que, si llegaba a imprimirse, le ocasionaría sin duda nuevas, mayores, incalculables desgracias?(192)

El meollo de Las palabras perdidas es, justamente, el intento de un escritor que aún no se siente capaz de escribir la historia que lo atormenta. Conversando con el Rubito en el restaurante moscovita, llega a sentirse ridículo cuando confiesa que quiere escribir una novela total, que incluya todos los géneros literarios, y el Rubito le contesta que si se creía Cervantes o Rabelais (318). Este deseo es un anhelo juvenil del Flaco en sus buenos tiempos (37), y le confiesa al Rubito que el título del texto, si llegase a realizarlo, es Las palabras perdidas, el nombre que le colocó el Rojo al prólogo de su texto sobre la antigua civilización kaärica. (316). Todo este juego con el narrador es una de las facetas más interesantes del relato analizado. Aunque el autor está representado en el Flaco, éste se enmascara detrás de un narrador en tercera persona en lugar de narrar en primera persona, en tanto testigo y protagonista de los hechos, para poder jugar con los pensamientos y sentimientos de los diversos personajes, asumiendo al mismo tiempo su punto de vista sobre lo que ocurre. Debemos recordar que los personajes no pueden hablar directamente por sí mismos, pues el narrador, correlato del Flaco en tanto autor ficcionalizado, es el llamado a rescatar sus vidas y palabras: ellos, el Flaco joven, Rojo, Una y el Gordo están silenciados. De este modo, el autor ficcionalizado:

[...] comparte con sus posibles lectores la aventura de escribir lo que ellos están leyendo, de ficcionalizar seres y acontecimientos; se detiene en las dificultades que se le presentan para estructurar un mundo fabulado, e incluso para nombrarlo y someterlo a un orden que se apropia del referente sólo para transformarlo[...] O comenta con sus interlocutores la inserción de tal escritura dentro del contexto de producción/recepción del género, exigiendo una competencia lectora cómplice [...] En síntesis, la representación de un creador que utiliza el territorio de la ficción para discutir su proyecto estético ideológico.(Bustillo 151)

Y ese proyecto estético-ideológico está vinculado con la conciencia de la relatividad estética, las múltiples tradiciones literarias, el peso del totalitarismo político en la vida colectiva e individual y la relación amor-odio con la literatura. Al mostrarnos el proceso mismo de escritura de un texto como una convergencia de razones subjetivas, sociales, políticas, económicas y estéticas, Las palabras perdidas nos involucra en todas las dimensiones de la escritura literaria:

Mientras que para la mirada convencional existen dos espacios claramente diferenciados: el del texto, por una parte, y, por otra, el del autor, la realidad, el lector y el contexto literario, la estructura de la novela autoconciente funde ambos espacios, desdibujando las fronteras entre el interior y el exterior, o, dicho de otra manera, haciendo una representación dinámica de las varias dimensiones involucradas, de tal forma que todas ellas quedan contenidas en la novela misma (en una primera instancia de mise en abyme...): The self- 
conscious text dramatizes and encapsulates its own context; and even when we aproach it through instrinsic criticism, it obligue us to practice biographical, rhetorical, literary-historical, and thematic criticism as well (1988:4-5) (Bustillo 149).

En la novela se representan las historias y obras de los jóvenes de El Güije Ilustrado —que conforman lo que llamaría Bustillo “el texto” como tal—y los problemas del autor —el Flaco maduro años después- y sus circunstancias. La vinculación entre ambas instancias se consigue por medio del juego de espejos que se desarrolla en la novela. El ejemplo más relevante de dicho juego es la espléndida mise en abyme que es el texto del Rojo, el "prólogo" a "Las palabras perdidas", que engloba la propuesta estética de la novela, el sentido de la literatura para la contemporaneidad, la insistencia en el carácter ficticio del texto, el conocimiento de la tradición literaria, la revista que quieren hacer los jóvenes y la valoración crítica de los textos de éstos:

Las palabras perdidas hizo honor a su título hasta que François, hijo de Maspero cuyas dotes de escritor y editor son bien conocidas, publicó en edición bilingüe cien ejemplares numerados y los envió a otros tantos colegas de diferentes lenguas con la solicitud de que lo retradujeran, distinción que fue aceptada de un modo tan entusiasta como unánime. Este empeño, que a mi juicio merece el calificativo de ecuménico, concluirá con la publicación simultánea del clásico kaärico en cien idiomas y más de doscientos países como culminación de las actividades de la UNESCO en el Año Internacional de la Poesía (157).

[...] El autor, no contento con darle forma de novela e incluir, sin embargo, cuentos, poemas y entrevistas —algunos de los cuales se supone que no estaban destinados al público—, nos sorprende, ¡a la altura de la página 153!, con un ensayo que es el prólogo de su propio libro; pero, según nos advierte paladinamente, tampoco éste es un texto definitivo, ya que su forma final siempre dependerá de los que aún nos falta por leer. Lo cierto es que Las palabras perdidas produce en el lector contemporáneo una alucinante impresión de postmodernidad.[...] Y temo que nuestra condición de occidentales habituados a pensar en términos de lógica binaria nos dificulte la comprensión de un libro escrito hace cuarenta siglos cuyos enunciados, sin embargo, adquieren con frecuencia el tono de lo cotidiano. (159)

El distanciamiento estético radical marca la impronta de la propuesta del Rojo borrar la autoría, contemplar un sustrato universal en la cultura, imaginar etapas en que la literatura, la palabra, eran culto, fundación y religión- y entra en tensión con el realismo del Flaco, quien quiere rescatar las historias y escrituras de sus amigos. Este fascinante contraste, que ha marcado los vaivenes de la estética contemporánea, es una respuesta muy actual a los dilemas de la creación literaria hoy. La ficción es capaz de darse todas las libertades espacio-temporales y culturales posibles, pero, al mismo tiempo, dialoga con nosotros desde la más estricta contemporaneidad, en tanto proceso de producción de significados que no se cierra. Las palabras perdidas enfatiza esta condición y nos ofrece múltiples caminos de lectura del texto, tal como puede verse en las siguientes citas: 
Pero Theodor W. Adorno, que se ocupa de la versión al alemán, nos ha enviado una cartacircular a los restantes traductores: "La gran diversidad no sólo de estilo sino también de géneros que se evidencia en la insigne traducción del insigne kaärologo francés”, sostiene Adorno, "prueba que el texto es una compilación de obras de varios autores, que se asemeja mucho a lo que en la actualidad llamamos una revista literaria”. Tuve ocasión de consultar al profesor Ambrose Fornet, que aún se hallaba en pleno goce de sus facultades mentales, y rechazó de plano la hipótesis alegando que el libro hace pensar más bien en una novela escrita con el único fin de dinamitar el género, como ha ocurrido tantas veces en Occidente. "La revista literaria que Adorno cree estar leyendo", me dijo textualmente, "no es otra cosa que el modo kaärico en que Urkimök Kaisso concretó el estallido”. (158)

Como dije anteriormente, es fundamental contemplar la dimensión metatextual de Las palabras perdidas, su carácter crítico y valorativo. Los nombres de críticos importantes de diversos países convergen aquí para jugar con las distintas definiciones y lecturas posibles de la obra. Efectivamente, Las palabras perdidas presenta los textos de la revista El Güije Ilustrado y el Flaco es el compilador de los escritos de sus compañeros, pero esos textos son el punto de partida para hacer una "novela total”, dentro de la más rancia tradición de rupturas estéticas de la modernidad. El texto es pues un "estallido" dentro de una literatura que requiere nuevos aires:

[...] En cuanto al género, Reis se muestra inconforme con las propuestas más recientes y prefiere atenerse — cito literalmente su misiva—: “a la clasificación que la sensibilidad de Henri Maspero supo respetar: Las palabras perdidas es un singular banquete de festraäg, esa fiesta agónica que hoy llamamos literatura”. (159)

Occidente se ha habituado a aceptar la separación entre libertad y poesía, reservándole a esta última una función puramente ornamental; de ahí la tranquilidad atroz, la irredimible angustia de los poetas occidentales, a quienes el poder ha reducido a esa mera condición de adorno contra lo que tanto luchó el malogrado Theodor Adorno.(159)

Aquí se define la percepción de la literatura mantenida por Rojo, Una el Gordo y el Flaco, que asumen la palabra y la escritura como destino y posible salvación frente al mundo, posición propia de la definición contemporánea de los poderes de la estética, más allá de los estilos y tendencias. Esta fiesta agónica es, pues, una posibilidad de darle sentido y brillo a la vida desencantada de los personajes, inmersos en los rigores de una revolución en medio de las contradictorias sociedades latinoamericanas. Y es la posibilidad, también, de rescatar la memoria:

Para ello es preciso detenerse en el uso kaärico de ciertos adjetivos que puede parecernos en extremo arbitrario, por ejemplo, "tutelar" aplicado a "castigo". Desde el punto de vista kaärico esta relación es no sólo hermosa sino también exacta porque en Nuestra Amada Kaär se habían perdido efectivamente ciertas palabras capitales, y constituía una obligación "tutelar" de los padres someter a sus hijos al "castigo" de la conciencia y la responsabilidad de dicha pérdida en una ceremonia de expiación poética, que era a la vez un acto de purificación. Téngase en cuenta que el insoportable sentimiento de angustia 
que los chinos llamaron “Horror de Nuestra Amada Kaär” no se debía a la aplicación del "castigo tutelar", sino a la prohibición del mismo por parte del emperador Kai Khan. El resultado fue la pérdida de la conciencia de que se habían perdido las palabras y la consecuente incapacidad de continuar luchando por alcanzar la poesía. Así empezó la era de decadencia que terminaría hundiendo a Nuestra Amada Kaär en el Mar Amarillo. (160)

Y para ese rescate de la memoria, es preciso valorar en toda su dimensión los textos de cada uno de los miembros de El Güije Ilustrado:

[...] Desde su punto de vista, el notable relato "Flores para su altar" testimonia una fase primaria de la religión kaärica, en la que era común el holocausto vinculado al sentido purificador del fuego. En cambio, el poema "Nana” de nuestra amada Kaär da cuenta de un rito iniciático correspondiente a una etapa posterior, donde ya el castigo se ejercía simbólicamente, en el plano de las palabras. Por último, expresa su curiosidad por saber qué analogías aportará "Fiesta”, un texto que aún está pendiente de traducción y análisis.(158)

“Réquiem”, por su parte, es el tipo de obra, a menudo magnífica, que suele florecer en los períodos de decadencia; el kaärico vulgar alcanza en este poema, que acusa una cierta influencia de "Flores para tu altar", su mayor lucimiento. Por último, nos dice Reis levantó la vista brevemente para ver a Una-, "Me confieso culpable ante los hombres" inicia en la cultura käarica lo que siglos después Occidente llamará extrañamiento, sometiendo la historia y la cultura de Nuestra Amada Káar a la mirada nueva y en cierto modo feroz de la mujer, no del todo exenta de rencor, de un modo análogo al atribuido por Brecht al proletariado [...]. (279)

Los mundos de el Rojo, el Flaco, el Gordo y Una

En Las palabras perdidas cada poema, cada relato, cada entrevista a un gran escritor, la organización misma de toda la novela, es cuidadosamente mostrado, relacionado, expuesto en su dimensión histórica y estética, con un criterio que propicia una lectura descentrada y lúdica al establecer múltiples líneas de fuga que nos llevan a propuestas literarias, etapas históricas, problemáticas políticas y sociales diversas. Es una actitud crítica que se ofrece prácticamente como un programa de ejercicio desde una óptica plenamente actual. Como dice Beatriz Sarlo:

El desafío [de la crítica literaria] es si podremos imaginar nuevos modos de considerar los valores, modos que (aunque parezca contradictorio) sean a la vez pluralistas, relativistas, formalistas y no convencionalistas. Una perspectiva relativista prueba que los valores varían según los contextos culturales. Según el relativismo deberíamos leer los textos en sus contextos y juzgarlos por las estrategias que emplean para resolver las preguntas que esos contextos consideran apropiadas. De este modo, la discusión de valores es siempre una discusión textualizada [...] Los valores son relativos pero no indiferentes (“Los estudios culturales” 36-37, énfasis mío). 
En Las palabras perdidas se asume el reto de valorar y rescatar un grupo de textos divergentes genérica y estéticamente, entendiendo que una de las constantes de los debates estéticos desde el siglo XIx es que la tensión entre propuestas radicalmente distintas es la condición necesaria para el surgimiento de nuevas opciones literarias (Bourdieu 376). Desde la mirada de hoy, que es la de la novela, propuestas tan disímiles como las de Nicolás Guillén y José Lezama Lima podían convivir en su dinámica de rechazo y atracción como parte del equilibrio del campo literario. Nuestra mirada desencantada sabe que en lo que a literatura se refiere nada es definitivo, todo es relativo; pero, Las palabras perdidas nos advierte que aunque nada es definitivo, tampoco nada es indiferente.

Por eso el empeño del Flaco — narrador de la novela — en llevarnos a las "palabras perdidas” del Rojo, el Gordo y Una, entre otros, a su diversidad y a sus exploraciones personales del lenguaje y a partir de ellos establecer las líneas de parentesco de la literatura cubana y latinoamericana entre sí y en relación con otras corrientes culturales. El lenguaje, nos indica el narrador de Las palabras perdidas, no puede ser indiferente para nadie, y, por ende, la lengua literaria no puede ser indiferente para sus productores y receptores. No se trata aquí del endiosamiento y los mitos alrededor del poeta como profeta, sacerdote, demiurgo y salvador de la humanidad, a los que los personajes de la novela estudiada son tan afectos. Se trata de comprender, dentro del campo literario en su conexión con el mundo político y la cultura, la diversidad e intenciones de los lenguajes en debate vistos como trabajo, producción de significados, oficio, y como un proceso activo que incluye desde luego al lector. En Las palabras perdidas se nos lleva por este camino a entender cómo los sectores letrados asumen su herencia cultural, a partir de la definición y redefinición constante del canon —en este caso representado por el quinteto Lezama, Guillén, Carpentier, Diego y Piñera - desde la óptica de escritores y público nuevos y a partir de su relación particular con el mundo político, relación que se encarna en la pregunta relativa a la función de la literatura y del escritor en la revolución.

Los textos del Gordo, el Flaco, Una y Rojo son una respuesta a todo esto, y son, además, modos de interpretar y modelizar al mundo, consustanciados absolutamente con las acciones de cada uno de ellos. Al develarse la propia naturaleza ficticia del texto, al ponerse en evidencia su proceso de construcción (Bustillo 12), los personajes de la novela —incluyendo los inspirados en sujetos históricos como Carpentier o Eliseo Diego- pasan a ser su palabra y no las pálidas sombras de personas que realmente existieron, o los canales para una denuncia sobre un régimen político. En el lenguaje especialísimo de todos ellos, en sus textos mismos, está la denuncia, y no nada más en la anécdota: por eso, entre otras razones, hay que salvar sus palabras del olvido. El sentido político de la literatura, nos dice esta novela, es que sus luchas estéticas implican una lucha por los modos de representación del mundo, los cuales no son inocentes pues implican nuevas y diversas formas de significación, muy distintas al carácter comunicativo e informativo de la lengua cotidiana o a los modos de representación ofrecidos por otros discursos artísticos, políticos, académicos, religiosos, etc. ${ }^{3} \mathrm{Y}$ esa representación no implica el acto mimético de

\footnotetext{
${ }^{3}$ Al respecto dice Renato Prada Oropeza (40): “El discurso literario conforma la "realidad” al ser una praxis, una práctica generadora de sentido y no meramente una actividad reproductora de la realidad socio-cultural: el mundo cotidiano expresado por la lengua es negado (en el sentido de la dialéctica
} 
ficcionalizar “un mundo previo” pues “[...] la contigüidad entre el discurso de la 'realidad' y el discurso literario no es un continuum unidireccional y monológico en el que las unidades culturales ideológicas ‘ingresan’ al texto, es una productividad caótica donde el juego de semejanzas y diferencias entre ambos discursos genera significaciones” (Gaspar 67). En Las palabras perdidas se ponen a dialogar instancias de significación cultural, políticas, sociales, genéricas, y de ese diálogo se desprende su propuesta en tanto representación literaria y en tanto denuncia política.

Y en este diálogo sobresalen los discursos de Una, Rojo, el Gordo y el Flaco. La estructuración del texto responde a sus diversos puntos de vista sobre sí mismos, sobre sus compañeros y sobre la literatura, pero de un modo distinto al de la defensa de la subjetividad romántica, aunque esa subjetividad sea sustancial para entender a los personajes. En esta novela, las miradas distintas de los personajes suponen “[...] la certeza del relativismo que impregna todas las relaciones del hombre con su entorno: desde las diferencias que marcan la mirada personal y desde la impronta de imaginarios culturales que condicionan la percepción y el lenguaje [...] (Bustillo 148). Y es que, efectivamente, el relativismo es la marca de la mirada del narrador de Las palabras perdidas, quien varios años después de la muerte de sus amigos, sabe que todos eran valiosos, aunque distintos, y que sólo un régimen totalitario puede imponer una sola manera de ver el mundo o una sola estética.

Veamos entonces la poética de cada uno de los protagonistas, comenzando por las del Rojo:

Allí, en la singular siembra de eucaliptos llevada a cabo como homenaje a Carlos Marx, había escuchado, mezcladas, todas las lenguas y dialectos de Europa, y aquella confusión babélica le sugirió la idea de un Idioma desconocido del que él supuestamente iría traduciendo sus poemas. Y a pesar de las burlas del Gordo abrigaba la porfiada certidumbre de que cuando lograra concretar aquel hallazgo podría romper la prisión del realismo, la servidumbre de la anécdota, la miseria del color local que, bajo los seudónimos de antipoesía, conversacionalismo y coloquialismo banalizaban hasta el hastío la joven poesía cubana creando la desoladora impresión de que todos los versos estaban escritos por el mismo pésimo poeta. (12)

[...] ya no se trataba de inventar un idioma únicamente, sino toda una cultura con su historia, sus mitos, sus gentes... Cuando él lo interrumpió, “¿Winnesburg? ¿Spoon River? ¿Sain Mary Mead? ¿Yoknapatawkpa? ¿Macondo? ¿Puebla Nueva del Conde? ¿Santa María? ¿Región?”, no pudo imaginar que el Rojo reaccionaría de modo tan soberbio, replicándole que ésos eran mundos incrustados en culturas existentes y que lo que él se

hegeliana) al ser "tomado"por el discurso literario para postular, gracias al trabajo que con ese material realiza, un mundo posible distinto, que abre nuevas posibilidades de significación y entendimiento ontológico de nuestro mundo y nuestra condición humana; posibilidades de significación alternativas, en cierto modo, frente al mundo cotidiano representado por la lengua y la semiótica del "sentido común”. De ahí la carga subversiva, en cierto modo, de la literatura, ya en cuanto serie cultural simplemente, respecto a los hábitos culturales manifestados por la lengua o la semiótica del "sentido común" (40). 
proponía era crear una suerte de civilización previa que... “¿Orbis Tertius?”, ironizó el Gordo, y el Rojo gritó que no lo comparara más con nadie, por favor, Orbis Tertius era una civilización paralela, desconectada de las reales, una simple curiosidad utópica, mientras que la suya sería previa a las históricas pero habría influido en ellas y por lo tanto le permitiría situarse en el centro de la cultura universal, echar mano de cuanto le hiciera falta, alcanzar la libertad absoluta sobre la base de vencer las mayores dificultades, hacerse amigo de sus modelos actuales o históricos, cartearse con Ibn Hazm de Córdoba, con el Marqués de Sade o con Fernando Pessoa y desbancar a Aristóteles si le daba la realísima gana. (114)

El Rojo nos remite a una de las estéticas más productivas y polémicas de América Latina, emparentada con la más rancia tradición letrada, cosmopolita y erudita, tanto europea como latinoamericana. Su figura tutelar dentro de la literatura cubana es, sin duda, José Lezama Lima, lo cual implica toda una lectura del mundo y de la cultura, en la que la magia de las correspondencias baudelerianas pone en contacto el sustrato universal del que se alimentan todas las culturas, y del que debe alimentarse el poeta desde la perspectiva de dueño de la palabra, de profeta y sacerdote de un culto secularizado como el arte, sustituto de la visión integradora de la religión como instancia generadora y justificación última de todas las cosas. El escritor, en tanto médium, destruye el lenguaje para, como dice Lezama Lima (134) en la entrevista que le hacen los jóvenes en la novela, hacerlo renacer de sus cenizas y fundar un mundo nuevo. Góngora, Borges, Martí, Rubén Darío resuenan en estas palabras. Nada es casual ni ajeno: la literatura es la posibilidad de darle sentido al caos aparente que nos rodea a través de la revelación del secreto sentido que late en la vida misma... Por eso el Rojo quiere ser el último profeta: no quiere parecerse a Borges, Onetti, García Márquez, Faulkner, Edward Lee Master... Quiere un mundo imaginario desde el cual el real adquirirá un sentido nuevo. Por eso el Rojo se topa con maravillosas coincidencias entre su texto y la existencia del sabio Henry Maspero, estudioso de Nuestra Amada Kaär, el mundo perdido del que el Rojo quiere dar fe:

"La estrella del destino de Nuestra Amada Kaär, oh, hija mía,

brilló una sola noche entre montañas hace cuarenta

[siglos;

fue tan bella

que su fulgor cegó por un instante a los guerreros.

\section{$[\ldots]$}

la estrella del destino brilló con sus palabras. ¿Qué dijeron?,

busquemos en Alej, él lo anotaba todo.

$\dot{¿}$ Te afanas, lloras, te interrogas, temes?

Perdóname, hija mía,

Es la condena de los nacidos en Nuestra Amada Kaär Mirar de frente

El punto ciego, el tokonoma, el horrendo vacío Que alguien creó en nosotros para siempre 


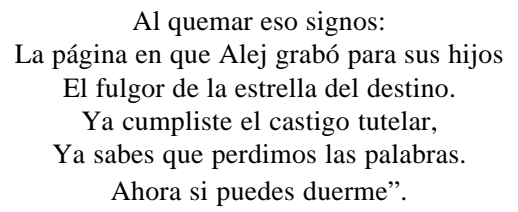

El sujeto lírico en este poema borra la instancia de enunciación, es decir, cualquier marca temporal, espacial, verbal que indique una voz que responda a una localización o época contemporáneas. Dentro de una concepción artística que contempla la distancia y la reflexión sobre el texto como elementos esenciales de una poética universalista, Rojo se niega a hacer ninguna concesión que implique que él como escritor es una suerte de funcionario público que debe hacer entender la "realidad de su entorno". Olímpico y aristócrata, es el más secretamente admirado entre todos los miembros del grupo porque su única pasión es la literatura y lo demás le importa un bledo. El Gordo y el Flaco lo admiran pero también lo cuestionan: no es un "poeta cubano”, lo cual sólo merece del Rojo una despectiva insinuación acerca de si quieren color local (140). Esta manera de ver el arte ocasionó discusiones extremas en toda América Latina a lo largo del siglo xx. Sólo hay que recordar la polémica Vargas Llosa, Cortázar, Collazos Literatura en la revolución y revolución en la literatura, la polémica entre regionalistas y cosmopolitas en toda América Latina, la irreverente posición de los estridentistas mexicanos, los ensayos de Alfonso Reyes, Pedro Henríquez Ureña y José Carlos Mariátegui, los modernistas brasileños, para entender que la discusión entre el Gordo, el Flaco, Rojo y Una nos remite a aspectos centrales de la literatura y el arte en América Latina. De lo que se trataba era de asentar nuestras diferencias con respecto a Europa, sintiéndonos parte al mismo tiempo de la cultura occidental. Pero, además, Rojo sabe que en la literatura se han logrado cosas que en otros aspectos de la sociedad: Lezama es su paternidad a destruir, pero también su herencia a tomar en cuenta dentro de la evolución de la literatura latinoamericana. Desea una feroz originalidad que lo hace un representante más en la larga, como diría Octavio Paz, "tradición de las rupturas” de la contemporaneidad, mas reconoce que la originalidad es sólo un resultado más en la vasta intertextualidad propia del discurso literario. Sabe que sus textos le deben a Lezama tanto como al Flaco, que le indicó que si iba a traducir sus poemas de una lengua imaginaria, debía crear una visión de mundo sustentada en esa lengua. El Rojo acepta, pues, que en el campo literario las tensiones y rivalidades son el punto de partida para la productividad estética: hay que matar a los padres y luchar a brazo partido con los amigos por ganar la primacía: ni con ellos ni sin ellos...

En el extremo opuesto está el Flaco: es mulato, instructor de filosofía, vive en un solar, no tiene modales ni sabe vestirse: es puro fuego y talento, y por eso el Rojo, con su clásica belleza, sus refinados hábitos, su menosprecio hacia la educación formal, su elegancia natural, lo acepta. El talento es lo primero y las diferencias sociales — pues las había con todo y revolución — deben quedar a un lado. Veamos su perspectiva literaria:

“Una ráfaga de eme dieciséis quemó la noche y el joven guardafronteras”... El Flaco hojeó las cuartillas con desgano; “aurea mediocritas”, murmuró, echando un vistazo al reloj 
de pared y luego al rostro de la secretaria, todavía recubierto por una sonrisa indescifrable. Se dijo que ahora dependía de la paciencia y volvió a refugiarse en sí mismo. No, el Rojo no tenía razón, no podía tenerla. Era cierto que en el solar resultaba virtualmente imposible escribir, que la sordidez de aquella vida lo tenía al borde de la locura, pero ¿qué remedio?... Vivía en una ciudad donde las casas estaban ocupadas y por tanto ninguna se alquilaba. ¿̇lba a dejar de escribir por eso? Meneó lentamente la cabeza pensando que el silencio equivaldría al suicidio y que su error, su verdadero error, consistía en haber intentado huir de la miseria, en no haberse metido en ella hasta los tuétanos para crear, desde el centro de aquella artesa donde ardía su vida, una narrativa realmente nueva (56).

Pero donde quizás queda más claro qué quiere hacer el Flaco con la literatura es este fragmento:

... y pelsiguiendo tu amor, quemao por dentro y pol fuera, yo me tuve quénfreltal, en la montaña émi vida, a los dientes de un león, de un lobo y de una pantera.

—A ver, explícame — dijo el Flaco de pronto—, ¿cómo Pichincho escogió los mismos animales del Dante? Explícame eso primero y después háblame de falta de distancia y de ambición y de aurea mediocritas.

—_Quién é er Dante ese, yérnica? — preguntó Pichincho parodiando las fintas de un boxeador.

—No sé — respondió el Rojo deseando más bien averiguar si “yérnica” sería un sinónimo de "ecobio" o simplemente una suerte de pronombre personal—. Los mismos animales... y la misma estrofa, el terceto — concedió, desconcertado—. Pero aun así lo que canta es folklore, no poesía.

—Ah, pero ven acá, ven acá — dijo Pichincho pasando su larguísimo brazo por sobre los hombros del Flaco y señalándolo a él con un índice de pianista, ¿de dónde coño tú sacate al pollo'e granja ette?

Sintiendo que se ruborizaba ante las carcajadas simultáneas, el Rojo se dirigió al negro: —En esta tumba pardusca/ yace quien tradujo a Dante./ Ten cuidado tú, cantante,/ no sea que te traduzca.

Pichincho abrió los ojos y la boca con un gesto de admiración infinita.

— ¡Ño, yérnica, utté é un bejtia! — dijo, echándole el otro brazo por sobre los hombros. - Somos yérnicas los tres —aventuró él, perseguido por otra carcajada.

Ya no cabía duda: "yérnica” era un pronombre personal; había dicho algo así como “Somos Tú los tres”, con lo que a través del absurdo había revelado la función simbólica del terceto en La divina comedia: expresar el Misterio de la Santísima Trinidad.

— ¿Por fin quien é er Dante ese, asere? —insistió Pichincho.

—Un poeta —respondió él.

— ¡Un coleguita! —exclamó alborozado Pichincho, e hizo sonar sus manazas en medio de una carcajada-. Denle el recuerdo del hijóe Fredejvinda.

—Viento en popa — dijo el Flaco, y llegó a la cola de la pila, gritando—:¿último?

— Hasta luego yérnica — se despidió el Rojo, que con el dominio de la palabra había recuperado el dominio de sí mismo. (44-45)

Ésta es la poética del Flaco y su lectura del mundo, un mundo en que Dante impregna los sentimientos de un cantante popular y le da forma a su visión de la vida, en el que las bestias de La divina comedia pueden caminar por el imaginario de un solar habanero transfiguradas por el habla iletrada de un trovador de barrio, y en el que un aristócrata como 
Rojo, un intelectual pobre como el Flaco y un sonero del solar se reconocen como pertenecientes a una hermandad: la santísima trinidad de lo popular, lo elitesco y la hibridez, de la que el Flaco quiere ser representante. Arguedas, Carpentier, Guimarães Rosa, resuenan aquí, y no es casualidad que uno de los anhelos de los escritores de los años cuarenta, cincuenta y sesenta haya sido lograr integrar las hablas múltiples de nuestros países, superando los contrastes entre habla “culta” e "inculta” que marcaron el regionalismo. Como el fragmento citado está escrito desde la perspectiva del Rojo, estos contrastes se sienten en plena tensión. Pero veamos este fragmento de "Flores para tu altar":

¡Ay Santísimo, ¿por qué Juancho había rechazado la protección de Changó? ¿Por qué no la entendió cuando ella dijo que el Rey del Fuego sabía compartir el cielo, que siempre lo había hecho, con Martí, con Jesucristo y con el mismísimo Sanfakón? ¿Por qué no permitió siquiera que Eléggua guardara su puerta? ¿Cómo se atrevió a decir, sin que se le quemara la boca, que él era comunista y que los santos lo perjudicaban? ¿No estaba clarísimo, Virgen de las Mercedes, que Juancho se había vuelto loco? ¿Y qué podía hacer una madre sino proteger a su hijo de su propia locura? (106)

Tradición y modernidad se mezclan en este fragmento, en el que el narrador en tercera persona utiliza el modo indirecto libre para narrar, desde los ojos de Candelaria Cárdenas protagonista del relato, los choques y sincretismos religiosos propios de los registros de la cultura oral cubana. El Flaco, autor de este relato, intenta cumplir su misión de entrar de lleno en el mundo del solar en el que había crecido y contemplarlo en sus tensiones con el modo de ver el mundo, más racional, introducido por la Revolución Cubana. Es un hombre del solar, pero el hecho de ser escritor e instructor de Marxismo lo aleja de la vida en que nació y creció, al responder a un proyecto de modernización propio de la Revolución. El narrador de su cuento entra en ese mundo y se distancia de él alternativamente a través de una perspectiva narrativa que se acerca al personaje protagónico para casi fundirse con él, pero al mismo tiempo se aleja con el fin de introducir claves para entender la situación de Candelaria, claves que ella misma no tiene, de ahí su confusión y su suicidio al final de la historia. Éste es el drama del letrado frente a las culturas orales: la letra lo impele a ir hacia ellas, y lo aleja pues los lenguajes no son inocentes: intentar relatar la experiencia de Candelaria es darle una explicación entre racional y piadosa a su drama de madre que pierde a su hijo varón en manos de una rusa que lo sustrae de la vida del solar. Pero en esta contradicción del letrado está su perdición y su ventaja: esa tensión productiva entre miradas y lenguajes que pugnan entre sí y de los que emerge una chispa de diálogo, comprensión y liberación de significados alternativos. Candelaria Cárdenas es vista desde un punto de vista letrado cuya mayor virtud es destacar esa contradicción flagrante entre su propia mirada y el mundo de la protagonista del cuento: sólo en la comprensión de la propia limitación podemos acercarnos al otro e intentar un difícil y necesario diálogo.

El Flaco, en tanto autor nacido y crecido en un solar, que a su vez está situado en la Cuba de la Revolución, no contempla su identidad como un destino. Dice John Beverly que la literatura separa al subalterno de su propia subalteridad, “del silencio de los pobres”, pues le insufla la "ideología del autor soberano" (23 y ss.), moderna y burguesa, frente a la humilde pertenencia a lo popular visto como voz colectiva. Estas líneas podrían 
describir al Flaco y a toda una tendencia de la producción narrativa continental, si no ocultara una situación de hecho que, gústenos o no, es la que vivimos la mayor parte de los latinoamericanos: el Flaco viene de un solar, pero también vive en medio de una revolución, y esa revolución es tan cubana como el mundo de Candelaria Cárdenas. La pertenencia a lo popular o a lo letrado no constituyen destinos: la única Latinoamérica no es la de las culturas populares y orales vistas como enclaves premodernos en sociedades modernas. Es también la de culturas y vidas en permanente ligazón y conflicto: esa ligazón y ese conflicto forma parte de nuestra hibridez cultural. Un cuento como "Flores para tu altar” trata de dar cuenta de esta situación desde la posición del letrado, que también nos pertenece en tanto latinoamericanos.

El Gordo nos habla de otra experiencia esencial latinoamericana: la experiencia urbana, el mundo de la ciudad y de lo cotidiano:

[...] Pienso..., y usted me perdonará por ello, que la función de la poesía no es meterse en esos asuntos sino cantar las glorias de la patria.

“Dule et decorum est pro patria mori”, pensó el Gordo, cayendo en la cuenta de que ahí estaba la trampa, porque sí, claro, ¿acaso no lo habían hecho todos los poetas bien nacidos?, pero, ¿y el universo, la ciudad, el amor, la noche, la rabia, el desaliento, el resplandor de los cocuyos, la tenacidad de las hormigas...? Empezaría por ahí, poniendo eso en duda... (97)

La poesía, compañero ministro, era una forma de conocimiento muchísimo más útil y profunda que la ciencia y la política, el nexo entre intuición y autenticidad producía un estado de gracia que en la antigüedad se atribuía a santos y profetas porque les permitía revelar verdades ocultas para la mirada común de los mortales. Ahí, compañero, residía la fuerza del Tao te kin, de la Biblia, del Popol-Vuh... Gracias a ella Cuba no se había revelado en la obra de un general, ni en la de un científico, sino en la de un poeta. Martí era... (99)

[...] La crisis de la ciudad, por ejemplo, la descomunal diferencia existente entre aquella fascinante Babilonia que había alcanzado a ver en su primer año de estancia en La Habana y el conjunto de calles y portales carcomidos por donde caminaba ahora. Pero no se sentía capaz de expresar esa catástrofe en palabras, necesitaba acabar de liberarse de la servidumbre coloquialista, aquella manera de decir que en un tiempo le había servido para romper con la magia esotérica del Poeta Inmenso y que, después de la crítica del Rojo y del Flaco, había empezado a resultarle incómoda, como un par de zapatos ajenos, demasiado pequeños. Para el Rojo, el lenguaje coloquial impedía tomar distancia; el Flaco lo llamaba trivialismo; él, en cambio, a pesar de todo en aquella antirretórica profesional existía una suerte de fuerza secreta, un núcleo que, al estallar, podía conducirlo a la gran poesía. Pero, ¿cómo llevarlo a ese punto? (99)

El Gordo pasó por alto la ironía. Era justamente eso, el folklore, lo que había objetado en el cuento del Flaco. Y ahora el Rojo le entregaba la antítesis, una suerte de antifolklore profesional. ¿Podría él realizar la síntesis, el perfecto equilibrio entre aldea y universo? Ya vería, ya verían todos... (140)

—QQué barbaro! —exclamó el Gordo—. Eso sí es poesía, no jodas...Eso sí es síntesis y humor y parodia y filosofía y política y resumen de esta época de mierda en que vivimos [...] (168) 
Los ecos de toda la discusión sobre la poesía conversacional resuenan aquí. Tal como plantean Saúl Yurkievich para el género poético y Antonio Skármeta para el narrativo, los escritores jóvenes de los años sesenta buscaban a conciencia un lenguaje coloquial y urbano que les permitiera dar la medida de su vida de ciudad, asumiendo todos sus registros pero sin perder de vista la necesidad de decantar un lenguaje que escapara de los usos comunes e informativos de la lengua. La influencia de Ernesto Cardenal, Roque Dalton, Nicolás Guillén, Pablo Neruda (el de Las odas elementales) y Nicanor Parra es evidente en una posición que pretendía terciar en la antigua polémica entre regionalismo y universalidad, a partir de la vivencia del latinoamericano urbano, equidistante de las pretensiones del universalismo cultural y de las limitaciones de telurismo y lo oral popular. El poeta es voz, profecía y primer ciudadano, desde una visión que privilegia su carácter de trovador, y habla de la belleza, la magia y el horror de la experiencia cotidiana. Veamos este fragmento de "Réquiem":

$$
\begin{gathered}
\text { "Esta ciudad nació en la sal del puerto } \\
\text { y allí creció caliente, deschavada, } \\
\text { el sexo abierto al mar, } \\
\text { el clítoris guiando a los marinos } \\
\text { como un faro de luz en la bahía } \\
\text { y dentro el Barrio Chino, Tropicana, } \\
\text { Floridita, Alí Bar, los Aires Libres, }
\end{gathered}
$$

Orquestas de mujeres musicando un chachachá bailado por marcianos. Hablaba, bozalona,

En una turba mezcla de yoruba y castilla, De calé, catalán, de bable y congo, $\mathrm{Y}$ todo ese patois, todo ese creole, Ese rico esperanto entreverado

De algarabías moras, chácharas cantonesas, Jerosimilitanas jergas de judíos,

bárbaro spanglish de bares y bayuses”. (220-30)

El sujeto lírico es el trovador que más que escribir poesía, pareciera irla recitando, o mejor cantando, a los que necesitan identificarse y reconocerse con y en un espacio vital. La cercanía del sujeto lírico a la materia del poema, se difumina discretamente para presentarse como la voz del iluminado, capaz de revelar los sentidos escondidos de la lengua cotidiana urbana. En este sentido, el poema del Gordo nos recuerda a los grandes canta-autores latinoamericanos, cuya solvencia poética no se reñía en lo absoluto con el sentido de la poesía como canto. Pensemos en Chico Buarque de Holanda o en la Nueva Trova Cubana. Desde luego, no debemos olvidar que el Gordo no es músico sino poeta, pero el sentido de su trabajo podría estar orientado en esta dirección.

¿Y que ocurre con Una, la única mujer del grupo? :

"Si hemos de darle crédito a la Biblia,

$$
\text { Yo, Eva, }
$$




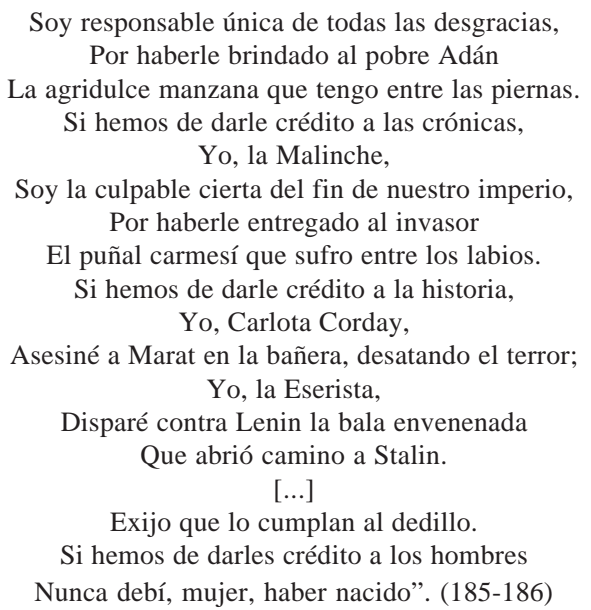

Una irrumpe entre el Flaco, Rojo y el Gordo a punta de pura literatura y talento. No tiene el atractivo físico que ellos le exigen a las mujeres, pero se parece demasiado a ellos en su posición vital frente al arte como para dejarla a un lado. La perspectiva narrativa favorece abiertamente a este personaje en cuanto a su juicio crítico y dimensión humana se refiere. En medio de las frecuentes mezquindades y competencias entre los tres varones, Una es la única, a pesar de que está enamorada del Rojo y, obviamente, siente debilidad por él, de justipreciar en toda su dimensión el trabajo de sus amigos y darle entrada en su propia vida al afecto y a la pasión amorosa con todas sus consecuencias. Parte de la agudeza y la amplia visión de Una le viene precisamente porque irrumpe desde los márgenes. En Las palabras perdidas se pone en evidencia la tensa relación de la mujer escritora con la historia y la literatura canónica. Una se siente empujada a interpretar la historia desde el punto de vista feminista, a rescatar un registro brutalmente subjetivo que se evidencia en el uso de la primera persona femenina en sus poemas, y a abrir el canon masculino a las escritoras:

[...] Pero cuando volvió a escribir poesía, después de meses de esterilidad, sintió que la vida recobraba su sentido. Además del libro de ensayos, haría otro, una especie de Antología de Spoon River, con las mismas escritoras suicidas como personajes. Al principio dedicó a ella todo el tiempo que le dejaba libre su empleo de diseñadora en una revista humorística; sin embargo, muy pronto sintió que la soledad consumía sus fuerzas. Marina [Tsvietáieva] estaba en lo cierto: la poesía era como hundir una aguja en el corazón. Y el suyo era demasiado frágil para soportarla. El dolor de no poder escribir la había sumido en un nuevo ciclo depresivo cuando supo de la convocatoria abierta de $E$ l Güije Ilustrado; para intentar salvarse se decidió a parir un poema de larga gestación que ya corría el riesgo de podrírsele dentro. (202)

Si en alguno de los cuatro personajes se nota el peso de la literatura como un destino es en Una. Sabe que en su caso la literatura está indisolublemente unida a su desgracia en 
tanto mujer sola golpeada y vejada por lo hombres, y víctima de un régimen político que la expulsó de la Universidad Lemonosov, en Moscú, por haber salido en estado de un africano. Los poemas duelen como duele la condición femenina misma, y, en particular, la condición de escritora que tiene que imponerse con su propia voz en un mundo masculino, y sufre terribles contradicciones porque rechaza a los mismos hombres por los que quiere ser apreciada, amada y reconocida. La actitud de Una ante el canon literario es análoga: quiere que se abra a las mujeres, sabiendo que la historia de la literatura es paralelamente una historia de exclusiones y poderes, pero también una historia de liberaciones. Para Una esa liberación puede venir por el lado oscuro y terrible del quehacer de la escritura más que por la simple apertura del canon a las escritoras. Por eso le dice al Flaco, al comparar su erudito cuento “Confución”(sic) con "Flores pata tu altar”: “Porque “Confución” (sic) pese a todo, es li-te-ra-tura — dijo mirándolo a los ojos—. Y ‘Flores’ está más allá, en el territorio de los iluminados o de los locos [...]” (308).

Una recuerda a las artistas modernas por excelencia, desgarradas entre la poesía, la pasión, el ansia de renovación y la conciencia de la marginalidad femenina. El dilema de Una implica una dimensión espantosamente trágica que la lleva al suicidio: en su condición de mujer despreciada, ni la literatura ni el amor terminan siendo un consuelo o una salvación. Una anduvo por la vida "como una perra vil, implacable, perversa,/ que a veces halla en su camino el premio:/ un hueso duro, asqueroso como un escupitajo” (312).

Esta radical amargura se equilibra en ocasiones con la espléndida visión crítica de Una acerca de la escritura de Rojo, el Flaco y el Gordo, visión que tiene que ver con que su conocimiento del canon literario está acompañada de la conciencia de la marginalidad femenina frente a él, lo que la hace ver que la discusión estética va más allá de la estética misma porque tienen también una dimensión genérica y política. Así, mientras el Flaco, el Gordo y Rojo se atrincheran en sus posiciones literarias, pensando que son las mejores y las definitivas, Una, como excluida, sabe que en literatura nada es la verdad última, a menos que el patriarcado, la supremacía blanca y el heterosexismo sean el natural destino de la humanidad. Es capaz de entender la obra de los tres porque como recién llegada a un canon que la excluye como mujer, sabe que el canon es mucho más diverso y heterogéneo, visto desde una perspectiva histórica, que lo que sus compañeros de grupo se plantean. Y es capaz también de rechazar las particulares cobardías de su amigos, que como árbitros olímpicos, cierran el paso a textos que podrían entrar en El Güije Ilustrado, la revista que tienen entre manos, pero que implicaría un desafío político para los burócratas culturales del régimen cubano. Entre las miserias del campo literario tenemos que la competencia por sobresalir individualmente puede llevar al traste las veleidades del arte por el arte, el arte como profecía o el arte como revelación: el Flaco, en particular, no quiere perder la pequeña cuota de poder que ha conseguido al ser el representante del grupo ante la burocracia de la que depende la publicación de la revista. Por eso rechaza "Fiesta brava”, el cuento del Mulo Bebelagua: el Mulo es homosexual y está sometido a un tratamiento de reeducación para que abandone sus inclinaciones, por orden del régimen cubano. Una está plenamente consciente de cómo las revoluciones y los escritores, entre ellos el Gordo, el Flaco y Rojo, reproducen los prejuicios burgueses que dicen rechazar: 
Y se volvió de espaldas maldiciéndolo en silencio. El Flaco debería saber que había llegado tarde a la novela precisamente porque él, misógino de mierda, había concebido originalmente el proyecto como la baraja española: sin mujeres [...] Restregó con rabia la sartén preguntándose por qué carajo la retórica se empeñaba en llamar a España "Madre Patria" cuando era obvio que había sido un "Padre Patrón", un macho obtuso e implacable, capaz de inculcar la intolerancia en la Isla con tanta fuerza que casi un siglo y una revolución después de la colonia, ésta seguía viva en la maldita manía de excluir a las mujeres y a los maricones de los verdaderos centros de poder. ¡Ah, pero África tampoco se salvaba!, pensó al oír al Flaco diciendo que no iba a publicar "Flores” porque estaba escribiendo otro cuento que sí prometía ser gran literatura [...] ¿Se podía ser más imbécil? ¿Cómo explicar aquella decisión inaudita sino a partir del hecho de que el Flaco tenía una moral abakuá, la masonería negra para la que los amigos eran dioses y las mujeres mierda? [...] Pero no, que se jodiera, después de todo ella era Sikán y no en balde el tribunal de los machos había mandado a cortarle la lengua. Su sitio era la cocina, su misión parir hijos muertos, su castigo permitir en silencio que los machos la agitaran, como hacía ahora el Gordo. (238)

Una es el golpe certero que devela las miserias y miedos del campo literario, entendido como las instituciones y actores que funcionan como instancias de consagración o rechazo y también como los grupos que quieren acceder al poder simbólico. Pero esa lucidez en Las palabras perdidas no significa reducir el ejercicio de la literatura a la pura institucionalidad —académica, editorial, crítica— o a la mirada del escritor que decide y define lo qué es o no literatura. Como dice Beatriz Sarlo (Escenas 155-156), el problema de la visión sociológica de Bourdieu es que junto con el mito de la libertad absoluta de la creación, desaparece también el problema de los valores desde el punto de vista estético: ¿qué nos queda entonces de la literatura? En Las palabras perdidas se nos da una opción: entender que los valores estéticos y la lucha por los modos de representar es una manera de entendernos como sujetos en el mundo, para bien y para mal, y que el lenguaje en la literatura se convierte en una posibilidad de activar la diferencia y la pluralidad cultural, social e ideológica. ${ }^{4}$

\footnotetext{
${ }^{4}$ Richard (Intersectando 358) defiende la literatura desde el punto de vista de su especificidad como discurso y de sus capacidades representativas, estéticas y políticas: "Los estudios literarios también han resentido la confusión generada por el proyecto de los Estudios Culturales de querer extender la noción de texto a la articulación semiótica de cualquier práctica social, sin ya atender la diferencia entre narración (volumen) e información (superficie), que separa lo directo de lo indirecto, la simbolización estética del trámite comunicativo. La crisis del paradigma de lo literario ha movido la interrogante -formulada por Beverley- de saber 'qué pasaría cuando la literatura sea simplemente un discurso entre muchos' (Beverley, Hay vida... 39), es decir, cuando se disuelva la frontera entre lenguaje cotidiano (instrumentalidad del lenguaje) y lenguaje poético (autorreflexividad y plurivocidad del signo).Es decir, cuando todo lo hablado y lo escrito se uniformen bajo el mismo registro banalizado de una mortal desintentificación del sentido, porque la palabra habrá dejado de ser teatro o acontecimiento para volverse simple moneda de intercambio práctico ya carente de todo brillo, fulgor o dramaticidad. Creo que la pregunta por el destino de lo estético-literario en cuanto voluntad figurativa de un signo estallado y plural que critica la masa comunicológica, también recae sobre la dimensión imaginativa del texto crítico, seriamente amenazada por una desapasionada lengua funcionaria que borra de sus trámites notificantes cualquier 'placer del texto': cualquier emoción o
} 
Precisamente por definirse en términos de esta lucha, los textos de los jóvenes son rechazados por los burócratas de la Revolución, cuya lectura de los mismos obedece a la más descarada manipulación ideológica: es una lectura literal, moralista y mimética en la que se trata de ver detrás de cualquier personaje, frase o alusión, un ataque velado o abierto a la Revolución Cubana. La mirada del censor, de acuerdo con Las palabras perdidas es la mirada que intenta ver en el lenguaje una transparencia absoluta: las palabras son las cosas y la literatura no es más que la transposición de la realidad a las palabras, con un grado despreciable de elaboración. Una alusión a un chino puede convertirse en una alusión a Maceo, prócer cubano, y el retrato de Julio Antonio Mella, fundador del Partido Comunista Cubano, desnudo, es una bofetada contrarrevolucionaria. Los textos y fotografías hechos o recopilados por los cuatro jóvenes se pierden por cuenta de esa lógica implacable de las dictaduras de cualquier signo: no hay hilo de la vida individual o colectiva que quede libre frente a los objetivos políticos del estado. El lenguaje, es, pues, de una importancia central para el totalitarismo, y la literatura es trabajo con el lenguaje.

Puede lucir hasta ingenuo y exagerado desde una mirada actual el interés de la Revolución Cubana por el arte y la literatura, sobre todo en una época como la nuestra en que se insiste en que el valor estético es un asunto institucional (Bourdieu), que ya ninguno de los dos cumple la función de enfrentar la censura y revelar verdades ocultas, ${ }^{5}$ y que la literatura, en tanto manifestación cimera de la cultura letrada es una activa productora de subalteridad, porque es una forma de colonización de registros propios de culturas orales (Beverley). Sin embargo, debemos entender que la literatura acompañó el quehacer político contemporáneo de diversas maneras, y que dentro de los proyectos educativos propios de las naciones latinoamericanas del siglo xx, ocupó un lugar central como promotora, constructora y salvadora de los valores de la identidad y del individuo. En Las

destello aún ligados al tembloroso perfil de palabras sugerentes bellas o ineficaces. Palabras capaces de actuar su disconformidad de estilos frente al "cálculo del saber categorial que trata de atrapar la inaprensibilidad del quién de cada sujeto en el qué de sus funciones destituyendo -de paso- 'la heterogeneidad de lo otro, el episodio inaudito del otro, todo lo que ese otro es cuando no sólo es vida útil, citándolo a comparecer en la categoría’” (Galende 55).

${ }^{5}$ Dice Idelber Avelar: “’Compensación’ quizás sea la mejor palabra para definir la demanda a la que respondía la literatura latinoamericana hasta las dictaduras de los años setenta: desde las proclamaciones eufóricas y , triunfantes, de Carlos Fuentes y Vargas Llosa sobre cómo la exitosa ficción del boom ofrecía un remedio (prefiero llamarlo consuelo) para el atraso material del continente, hasta los desocultamientos de la 'verdad censurada' llevados a cabo por el naturalismo testimonial o por la novela-testimonial o por la novela-reportaje, la literatura hegemónica de ese período se legitima a partir de una estrategia compensatoria. Si hoy no hay que desocultar -tanto porque la censura ha sido reemplazada por un régimen de sobreexposición y saturación de los signos, como porque los desvelamientos de las ideologías han sido ya completamente absorbidos por la ideología en cuanto tal-, la literatura se ve obligada a replantearse su lugar en una época postcompensatoria. Algo suena a pérdida aquí: nos habíamos acostumbrado a pensar, orgullosos, en la literatura como portavoz privilegiada de un discurso de identidad, sea él continental, nacional, o individual; o aun, en buen estilo ilustrado, como desenmascaradora de los mitos oficiales. El lector de João Gilberto Noll, de Tununa Mercado, de Gonzalo Contreras, de Diamela Eltit -algunos de los ficcionistas que han sabido pensar la crisis de la compensación- se da cuenta de que algo ha cambiado profundamente aquí” (42). 
palabras perdidas la revolución exige de los nuevos escritores un compromiso expreso y transparente con el proceso, un lenguaje hecho para comunicar significados inequívocos, o, en palabras de Nelly Richard “una lengua funcionaria” (358). Y ni siquiera se trata de que la Revolución Cubana aupase, al estilo estalinista, una u otra estética en particular: se trata de controlar toda forma posible de disidencia. Y la palabra, en aquel momento histórico, era considerada una de las formas más peligrosas de la disidencia.

El Flaco sigue obsesionado años después por esas palabras apenas conocidas por un grupo minúsculo y unos censores que cambiaron su vida y la de sus amigos muertos para siempre. Quiere escribir una novela que los haga hablar a todos desde su intimidad, su subjetividad y su peculiar manera de contemplar la literatura como modo de entender, constituir y vivir el mundo. Como diría irónicamente Bourdieu (485), estos jóvenes intentan por todos los medios enfrentar a la illusio del sentido común, del simple vivir en el mundo dado, la illusio de los príncipes del reino literario, sabios e iluminados: la existencia es, pues, una aventura literaria. Pero la gracia de esta novela no reside en esta suerte de canto de cisne del arte moderno, sino en cómo esta nostalgia y este dolor por la pérdida del arte como justificación vital absoluta se aúnan a la comprensión del funcionamiento del campo literario como un campo de fuerzas en las que conviven en tensión el canon y el contracanon, la angustia ante las influencias de los grandes escritores, el conocimiento de la literatura internacional, las mezquindades y egoísmos de los poetas y narradores —incluidos los jóvenes protagonistas-, las estrategias para ganar terreno y protagonizar e influir dentro de la lucha estética desde la creencia imbatible de que en la literatura sólo valen las posturas estéticas sin matices, la presencia insoslayable de la política.

Por todo lo antes expuesto, el tratamiento del sujeto textual ${ }^{6}$ en esta novela es de una especial complejidad. Los personajes del Flaco, Una, el Gordo y el Rojo fungen de intermediarios entre el narrador de esta historia — representado en el Flaco pero que a su vez se oculta en un narrador omnisciente que conoce los pensamientos, anhelos y secretos de los personajes - y nosotros en tanto lectores. Los cuatro personajes principales son, como ya dijimos, una visión de mundo y una perspectiva estética específica, pero no funcionan como exponentes, ejemplos, metáforas, como subjetividades borradas por la fuerza del juego de espejos poéticos y narrativos que propone la novela. No: son sujetos capaces de responder, reaccionar y cambiar frente a las demandas del entorno cotidiano desde su caracterización como personajes masculinos, femeninos, con una infancia,

${ }^{6}$ El personaje es la instancia de intermediación discursiva entre el sujeto de enunciación y el sujeto de la lectura, es objeto del diálogo implícito en el acto de narrar (Kristeva 113), y, a la vez, sujeto y agente del acontecer novelesco. El proceso narrativo confluye, desde esta perspectiva, en la constitución del sujeto textual, cuya evidencia más inmediata es el personaje, aun cuando es irreductible a éste pues implica todos los elementos participantes en la constitución del relato. La profunda densidad y complejidad significativa propia del sujeto textual -en el que convergen instancias semiótico-discursivas contradictorias, relacionadas con la creación y recepción del texto y elaboradas y recreadas a fin de ampliar el horizonte de lo "real"- es la razón por la cual los lectores de literatura -por lo menos los no especialistas- disfrutan de la dimensión humana y cultural de la representación, del fruto de un proceso de construcción de un mundo ficcional con características propias. 
formación, experiencia e historia particulares. Convergen en ellos instancias de significación múltiples y contradictorias — literarias, políticas, sociales— que se hacen visibles a través de las numerosas marcas de identidad que los caracterizan, y que emergen del diálogo productivo entre la perspectiva narrativa del texto, la evolución particular de los personajes y la perspectiva del lector. Del Rojo, Una, el Gordo y el Flaco sabemos desde cómo son físicamente, hasta dónde viven, con quién, quién les gusta o no sexualmente, qué hacen cotidianamente, sobre qué temas conversan y qué piensan. Son personajes urbanos que viven todas las contradicciones, bellezas y horrores de una modernidad contradictoria y, como tales, responden a una definición histórica de la vivencia de la subjetividad, y son mostrados en la variedad y transformaciones de sus posiciones de sujeto (Smith 39). En otras palabras, en sus cambios y contradicciones a lo largo de su búsqueda desesperada de identidad en un mundo signado por limitaciones ideológicas, económicas, políticas y sociales de diverso tipo. El narrador interviene para contextualizarlos y coordinarlos en función de respetar sus voces y nosotros, en tanto lectores, nos ubicamos desde diversas y divergentes posiciones estéticas e ideológicas. De la construcción del sujeto textual, producto de este diálogo entre todas las instancias narrativas — narrador, personajes, lector- emergen distintas visiones de la Revolución Cubana, en tanto una de las grandes utopías de la modernidad continental, y de todo lo que ha significado la literatura en la modernidad.

\section{Jesús Díaz y LA LITERATURA COMO RESISTENCIA}

Toda la obra de Jesús Díaz — escritor, guionista, ensayista y director de cine- está marcada por un genuino interés en la exploración de géneros literarios o no, el cual se manifiesta abiertamente en novelas como Las iniciales de la tierra (1987), en la que la cultura de masas se hace presente para entender el modo en que el protagonista ve su mundo, y que está estructurada respondiendo al esquema de un cuestionario para aspirantes a militantes del Partido Comunista Cubano. Lo mismo puede decirse de La piel y la máscara (1996), en relación con el cine y su influencia sobre la arquitectura novelística y sobre las percepciones de la vida cotidiana. En los cuentos de Los años duros (1966) el énfasis se coloca en la construcción de un discurso juvenil y coloquial que dé cuenta de la vida cubana posrevolucionaria desde el punto de vista de los que se han hecho adultos en ella. Pero, por sobre todo, la gran obsesión de Díaz es Cuba, lo cual lo hermana con los numerosos escritores del continente que contemplan la novela como un modo de revisar la existencia misma de sus naciones (Ortega 120). En Dime algo sobre Cuba (1998) explota el desengaño y la amargura de los que se sienten traicionados por la revolución, ya evidente en los textos anteriores de este escritor. Los personajes de todos estos relatos pueden hermanarse perfectamente con los de Las palabras perdidas: perdedores, marginales inteligentes, vapuleados por la vida, desesperanzados y víctimas de un tiempo histórico difícil. Pero en todos ellos se encuentra presente, igualmente, una firme convicción de la subjetividad como una posibilidad aunque sea mínima de resistencia y recuperación de un lugar para vivir, desde un ángulo de visión que no privilegia precisamente un individualismo a ultranza sino una definición del sujeto como entidad profundamente marcada por la historicidad que le es propia. En Díaz, la literatura es un discurso capaz de darle forma al 
dilema de la subjetividad en toda su contingencia histórica. Como dice el propio Pierre Bourdieu, cuya posición sociológica es insospechable de romanticismo, individualismos pequeño-burgueses o desplantes estético-sacerdotales:

No hay mejor prueba de todo lo que separa la escritura literaria de la escritura científica que esta capacidad que le pertenece por derecho propio, de concentrar y condensar en la singularidad concreta de una figura sensible y de una aventura individual, que funciona a la vez como metáfora y como metonimia, toda la complejidad de una estructura y de una historia que el análisis científico tiene que desarrollar y extender muy laboriosamente. (51)

Y esta intención es la que subyace en Las palabras perdidas en tanto problematización de la representación literaria. Esta novela erige la lengua en centro mismo de un conflicto por los modos de representación literaria pero, al mismo tiempo, desmitifica la palabra en el sentido de que deja ver todas las contradicciones y miserias del campo literario: autores, editores, críticos, instituciones - pero no para anular su poder estético sino para entender su valor en tanto posibilidad de dar a conocer una posición ante el mundo, una voz, una resistencia ante el olvido y la capacidad homogeneizadora desde el punto de vista cultural del mercado y del estado. La representación literaria nos permite la posibilidad de dialogar con la cultura desde perspectivas divergentes: leer el mundo a través de Lezama Lima, Carpentier, Diego o a través de Una, Flaco, Gordo y Rojo implica conectarnos con dimensiones socioculturales que los lenguajes de los medios de comunicación, la cultura de masas, las disciplinas académicas, no pueden abordar por sus propias características. No se trata de que la literatura sea mejor o peor que otros discursos: simplemente es distinta y en eso reside que todavía tenga poder de penetración en ciertos sectores sociales (Sarlo Los Estudios Culturales 39). Si, efectivamente, nuestra percepción del mundo está marcada por la hegemonía de la cultura letrada, ${ }^{7}$ no creo que otras percepciones independientes de ésta sean necesariamente mejores desde el punto de vista político o cultural. ${ }^{8}$ Las palabras perdidas adelanta una concepción de la literatura como discurso

\footnotetext{
${ }^{7}$ Al respecto dice Beverley: “[...] Lo que [Ángel] Rama descubrió en La ciudad letrada es que la literatura fue y sigue siendo en América Latina precisamente una práctica constitutiva de las elites -hipótesis adelantada en parte por Alejandro Losada en su trabajo sobre el romanticismo peruano. Aún en formas 'progresistas' -para emplear la conocida consigna de los sesenta-, es quizás más parte del problema que de la solución. Las contradicciones entre literatura y cultura vernacular se hicieron menos agudas, pero de ninguna manera desaparecieron con las campañas de alfabetización introducidas por la Revolución Cubana o nicaragüense o el proyecto de los talleres de poesía de Ernesto Cardenal. Otra vez, la idea de alfabetización implica que una forma de cultura, la print culture, es necesaria para ejercer los deberes de un ciudadano o una ciudadana” (23 y ss.).

${ }^{8}$ Dice Beatriz Sarlo (Los Estudios Culturales 36): desde una perspectiva transcultural los valores son relativos en el espacio global donde las culturas son iguales (como los ciudadanos son iguales). Pero no todos los valores de una cultura (esto ya ha sido argumentado por Habermas), merecen la misma estima si se les considera desde contextos extraños a esa cultura. Los valores son relativos pero no indiferentes. Y para cada cultura los valores no son negativos desde el punto de vista intratextual. Las culturas pueden ser respetadas y al mismo tiempo discutidas.
} 
alternativo de la subjetividad frente a ciertos poderes políticos, sociales y culturales, que en la novela se aglutinan en la presencia asfixiante del Estado cubano.

En esta labor de decantación de toda una experiencia histórica y cultural que ha marcado a todo el continente, los textos de Díaz dejan a un lado los mesianismos propios de los escritores del "boom” y la creencia en el poder sacerdotal de la palabra (Daus 320); de Las palabras perdidas, en particular, se desprende una idea mucho más atemperada y ponderada del quehacer literario: la posibilidad de encarnar esa experiencia otra, que nos singulariza frente al “[...] cálculo del saber categorial que trata de atrapar la inaprensibilidad del quién de cada sujeto en el qué de sus funciones destituyendo — de paso- 'la heterogeneidad de lo otro, el episodio inaudito del otro, todo lo que ese otro es cuando no sólo es vida útil, citándolo a comparecer en la categoría”" (Galende 55 citado por Richard “Intersectando...” 358). Como dice el sociólogo José Joaquín Brunner (30-31) la literatura (amén de la televisión, el cine, el periodismo) puede hablar de cómo la gente vive, padece y goza su existencia presente, lo cual le está vedado a la sociología, perteneciente a ese “saber categorial” del que habla Richard. El Flaco, Una, El Gordo y el Rojo viven y gozan su vida desde el pesar cotidiano y desde su posición de escritores urbanos, tremebundos, conscientes de todas las corrientes y todos los vientos culturales. Son, pues, criaturas urbanas, que viven de la duda, que no creen en la utopía y el progreso que les quieren vender, que se burlan de todas las tradiciones y que saben que viven en un mundo desmemoriado y cínico. Su búsqueda de absoluto en la literatura es trágica, marcada por todas las mezquindades propias de la lucha por el poder en el campo literario, romántica e ingenua en medio de una época que, ya hace treinta años, prefiguraba el mundo sin utopías en el que vivimos actualmente. Son latinoamericanos "ilustrados" que viven todos los problemas que aquejan a otros sectores sociales, son ignominiosamente "modernos" en una sociedad híbrida y contradictoria. Son entonces pasto y producto de la literatura y no de la especulación sociológica, que tan perfectamente le cuadra a cierta visión norteamericana que privilegia lo latinoamericano en tanto culturas tradicionales, memoriosas, afincadas en lo colectivo y en la tradición. En Las palabras perdidas se demuestra sin ambages que los latinoamericanos —ilustrados, letrados, pequeñoburgueses - tenemos, como dice Beatriz Sarlo (Los Estudios Culturales 37), derecho a la estética, hemos estado inmersos en la discusión estética desde siempre y participamos por derecho propio en ella. La pluralidad de estrategias poéticas y narrativas, la comprensión del lugar que ha tenido cada una de las estéticas modernas, la exploración de las virtualidades de la lengua y la reflexión sobre el proceso narrativo, nos llevan a la comprensión de nuestras complejas modernidades, y nos hablan de un texto que obedece a una concepción de lo literario como "[...] un discurso de alto impacto, un discurso tensionado por el conflicto y la fusión de dimensiones estéticas e ideológicas [...]” (Sarlo Los Estudios Culturales 36).

\footnotetext{
${ }^{9}$ Véase la nota 4.
} 
BiBLIOGRAFÍA

Avelar, Idelber. "Bares desiertos y calles sin nombre: literatura y experiencia en tiempos sombríos”. Revista de Crítica Cultural 9 (1994) 37-43.

Beverley, John. “¿Hay vida más allá de la literatura?”. Estudios 6 (1995): 23-40.

Bourdieu, Pierre. Las reglas del arte. Génesis y estructura del campo literario. Barcelona: Anagrama, 1995.

Brunner, José Joaquín. "Sobre el crepúsculo de la sociología y el comienzo de otras narrativas”. Revista de Crítica Cultural 15 (1997): 28-31.

Bustillo, Carmen. La aventura metaficcional. Caracas: Equinoccio, 1997.

Díaz, Jesús. Las palabras perdidas. [1992]. Barcelona: Anagrama, 1996.

Daus, Ronald. “La literatura novísima en América Latina.” ECO 267 (1984): 305-20.

Gaspar, Catalina. "Realidad, ficción e ideología: la productividad interdiscursiva”. Escritos 7-8 (1997): 63-70.

Ortega, Julio. El principio radical de lo nuevo. Postmodernidad, identidad y novela en América Latina. México: Fondo de Cultura Económica, 1997.

Prada Oropeza, Renato. Literatura y realidad. México: Fondo de Cultura Económica.

Rama, Ángel. "Los contestatarios del poder”. La novela latinoamericana (1920-1980). Bogotá: Procultura, S.A, 1982.

Richard, Nelly. La insubordinación de los signos. Cambio político, transformaciones culturales y poéticas de la crisis. Santiago: Editorial Cuarto Propio, 1994.

. "Intersectando Latinoamérica con el latinoamericanismo: saberes académicos, práctica teórica y crítica cultural”. Revista Iberoamericana LXIII/180 (1997): 34561.

Salabert, Pere. “Arte, tiempo, identidad”. Fin de un siglo: las fronteras de la cultura. Rosario: Homo Sapiens Ediciones, 1996. 15-45.

Sarlo, Beatriz. Escenas de la vida posmoderna. Intelectuales, arte y videocultura en la Argentina. Buenos Aires: Ariel, 1994.

. "Los Estudios Culturales y la Crítica Literaria en la encrucijada valorativa". Revista de Crítica Cultural 15 (1997): 32-37.

Shaw, Donald L. Nueva narrativa hispanoamericana. Boom. Postboom. Posmodernismo. Madrid: Cátedra, 1999.

Skármeta, Antonio. "Perspectiva de los novísimos”. Hispamérica 28 (1981): 49-64.

Smith, Paul. Discerning the Subject. Minneapolis: University of Minnesotta Press, 1988. Williams, Raymond. Marxismo y literatura. Barcelona: Península, 1980.

Yúdice, George. “'¿Puede hablarse de postmodernidad en América Latina?”. Revista de Crítica Literaria Latinoamericana 29 (1989): 104-28.

Yurkievich, Saúl. “Memoria y balance de nuestra modernidad”. Imagen Latinoamericana 100 (1993): 51-56. 